Article History:

Submitted:

23 November 2021

Reviewed:

18 December 2021

Edited:

20 December 2021

Article Accepted:

28 December 2021

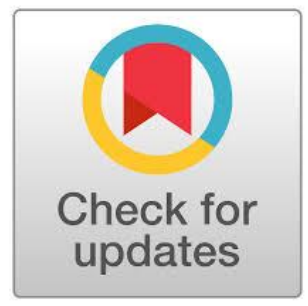

\section{A Cultural-Historical Activity Theory (CHAT) Analysis on Educational Psychology Class: The Challenges in Delivering a Fully Online Classroom Environment}

\author{
Erina Andriani*), Aletheia Ajeng Priskananda, Markus \\ Budiraharjo \\ Master's Program in English Education, Sanata Dharma \\ University, Indonesia
}

*) Corresponding author email:

andrianierina@gmail.com

DOI: https://doi.org/10.18196/ftl.v7i1.13196

Abstract

In assisting students' transformation, classes provide activities with face validity. This paper aims to provide readers with a cultural-historical activity theory (CHAT) analysis of an Educational Psychology class at a private university in Yogyakarta. Activity theory is a theoretical framework for studying and interpreting human interaction through instruments and objects. It provides a holistic and contextual discovery approach that can be used to help qualitative and interpretive research. Activity theory is especially important in circumstances with a large historical and cultural context and where participants, their goals and tools are in a state of rapid and continuous change. Few studies explored the use of the CHAT framework to reveal the challenges in providing a fully online class in higher education. Therefore, this study intended to explore the practical importance of CHAT for delivering a class in a fully online learning environment. The results revealed the CHAT framework units of analysis (UoA). In addition, the students shared some challenges they faced concerning those units of analysis. The implication of this study is to utilize the CHAT framework as a tool to evaluate the learning process.

Keywords: activity theory; CHAT; educational psychology; online learning; teaching strategies 


\section{Introduction}

Every learning-teaching process has activities in some forms to mediate students' transformation. CHAT is the tool that distinguishes and considers physical and abstract tools. Focusing on internalization can shed light on how tools, information, and practices are appropriated and routinized. By examining the physical tools used, we can understand why certain tools are chosen over others (Allen, Karanasios, \& Slavova, 2011). According to CHAT, contradictions are significant aspects of an activity system because CHAT values them as bridges for individuals as well as the entire activity system to develop and transform through a community of practice (Saka, Southerland, \& Brooks, 2009). Therefore, it can be used to analyze the activity system in Educational Psychology classes.

Educational psychology is a branch of psychology that studies children in an educational setting and is concerned with teaching and learning methods, cognitive development, and aptitude assessment. In this class, the students are the center of the learning process. As the target class, the Educational Psychology class is one of the subjects for first-semester students. The materials involve learning theories, metacognition, self-regulated learning, multiple intelligences, emotion regulation, motivation, self-efficacy and attribution, constructivism, individual differences, and critical thinking skills. The main weekly learning activities are making a presentation video for each presenting group, discussing the topic of the presentation video, and reviewing journals regarding the topics prior to the discussion session, while the final project is a publishable paper.

Because of the COVID-19 outbreak, the Educational Psychology class has become fully online. The learning-teaching means are mediated with synchronous and asynchronous media. Some argued that online classes are less effective than offline ones (Baralt, Gurzynski-Weiss, \& Kim, 2016; Tang, 2019). However, it can be flexible if teachers integrate interactive tasks (Gacs, Goetler, \& Spasova, 2020). Indeed, as the obligatory class meetings have been significantly reduced, the learning relies on a task-based method. As project-based learning can be advantageous for online classes (Gacs, Goetler, \& Spasova, 2020), this class uses mobile-assisted task-based language teaching (MA-TBLT). Task-based learning focuses on students' learning experience in performing tasks (Estarki \& Bazyar, 2016; Namaziandost, Bohloulzadeh, \& Pazhakh, 2017). The current development of task-based learning integrates technology to 
mediate the learning process (Thomas \& Reinders, 2010; Arvanitis, Krystalli, \& Panagiotidis, 2016; Ziegler, 2016). Though it has advantages in online learning, MA-TBLT also possesses challenges in both teachers' and students' perspectives (Chong \& Reinders, 2020).

It is the first semester to run fully online since the COVID-19 pandemic, and many things have gone unplanned. In addition, no one knows how long the online learning environment will be. Though the institutions have brief experience from the previous semester to evaluate and improve the new school year, the lack of experience and training in the educators' and learners' parts have caused issues throughout the learning process (Baralt, Gurzynski-Weiss, \& Kim, 2017; Chong \& Reinders, 2020; Francisco \& Barcelona, 2020; Tang, 2019).

Some previous studies highlighted the use of online classes as a feasible alternative (Chong \& Reinders, 2020; Francisco \& Barcelona, 2020; Tang, 2019). Some also mentioned the drawbacks of online classes, the issues and challenges from teachers' and students' perspectives (Baralt, Gurzynski-Weiss, \& Kim, 2017; Francisco \& Barcelona, 2020; Tang, 2019). However, few studies analyzed the challenges in online classrooms using the CHAT framework, especially in the Indonesian context. Therefore, researchers aimed to analyze the tensions, conflicts, and issues in an Educational Psychology class from a cultural-historical activity theory (CHAT) perspective. As research, CHAT takes human consciousness into account in an activity. In that relationship, all aspects concerning the activities and learners affect students' preferences and learning. As those assumptions make each unique and may affect learning progress, the authors employed CHAT studying individual assumptions. The classroom activities were heavily based on online learning with a task-based approach. The authors also integrated MA-TBLT in the analysis. 


\section{Research questions:}

1. How were the units of analysis in an Educational Psychology Class like?

2. What were the challenges that the students faced in an Educational Psychology class?

\section{Literature Review}

Activity theory has seven components that support them to run well. Those components are subject, object, outcome, tool, rule, community, and division of labor.

\section{Subject}

A subject refers to the parties included in the activities and performs the actions to achieve certain objectives. Furthermore, community members have to carry out their roles effectively for the subjects to achieve expected outcomes. To effectively moderate online discussions, online tutors and moderators need to adopt social, pedagogical, and intellectual roles (Vlachopoulos \& Cowan, 2010) and give individual support to the students (Quinton \& Allen, 2014). The shift in students' and lecturers' roles is crucial. It refers to ideas about the social and material aspects of learning processes developed by Alexei Nikolaevich Leontiev (1981) and Lev Vygotsky (1978). Engeström (2015) expanded Leontiev's (1978) ideas to a triadconnecting subject, tools and object and broadened the system to include community, the people who may share the same motive, rules presiding over the community, and division of labor that mediate collective actions that participants carry out.

\section{Object}

The object refers to the activities being acted on to reach a certain goal. Davydov (2008) stated that "practical, object-oriented productive activity-labor-is the basis of all human cognition” (p. 85), thus linking labor with education. The most crucial dimension that separates one type of activity from another is the object of the activity. In the context of education, it can be argued that the goal of the learning activity is to produce citizens who have knowledge and skills to be part of society. The theory assumes that activities are motivated by transforming an object into an outcome. An object can be a material or an idea. Referring to Leontiev (1978), an object, students' academic performances, is turned into an outcome. He emphasized the importance of the object of an activity, which is related to the goals and motives of the 
participants. In addition, he showed distinct differences between object-oriented activity and goal-directed actions (Yamagata-Lynch, 2010).

\section{Outcome}

The outcome is the goal that the activity subjects are expected to achieve. The activities are directed to achieve the outcome (Issroff \& Scanlon, 2002; Roth \& Lee, 2007; Roth \& Tobin, 2002). All means of the activity system play roles in the said alteration through mediation (Gedera, 2015; Nussbaumer, 2012; Postholm, 2015).

\section{Tools}

The tools are the media used to ease and assist the processes in conducting the activity. Tools are used "for revealing the social and material resources that are salient in activity" (Roth \& Lee, 2007, p. 197). We intended to use these theoretical tools to highlight what teachers hoped to gain from the activities and whether the supports affected students' development of academic skills and produced reliable test results that could be used to compare and rank students, teachers and their schools. Vygotsky's ideas about learning concentrate on the notion that cultural tools and signs mediate learning activities and that learning is a matter of assisted performance. Engeström's (2015) expanded activity theory offers other analytic tools appropriate for modeling activity systems.

\section{Community}

In the community, the activity subjects work together to achieve the objectives. The community allows cooperation with different sets of labor divisions depending on the needs to reach the objectives (Nussbaumer, 2012).

\section{Rule}

The rules are made to direct and manage the activities. Without the rules, there might be clashes of interests that prevent or hinder the achievement of the outcomes (Issroff \& Scanlon, 2002). The rules are made to prevent those obstacles and maintain order. They can be made by a certain authorized party or group collectively to strike a compromise (Jonassen \& RohrerMurphy, 1999; Postholm, 2015).

\section{Division of labor}

The division of labor includes vertical (position) and horizontal (task distribution) divisions (Engestrom, 2000). Division of labor is also about how students manage their learning. 
One's learning can be seen from self-regulation, including planning, monitoring, control, and reflection (Pintrich, 2000).

Some previous studies were conducted by utilizing CHAT to evaluate the delivery of learning activities. Engeström, \& Pyörälä (2020) shared the utilization of the CHAT framework to evaluate the formative interventions in healthcare. In this case, they could figure out their challenges and the physicians needed to develop collaborative and transformative expertise. In the education context, Gedera (2015) utilized activity theory to evaluate blended learning for university classes. The study exhibited activity theory to identify the tensions and contradictions during blended learning. Postholm (2015) shared the possible methodologies that could be used to implement activity theory for school-based development. As the students are the ones to conduct the activities, they may face some issues in the online learning environment. The students might feel alone in their learning process, as online learning lacks a sense of community (Stewart, 2008; Turner \& Hussman, 2008). Concerning the object of the activities, the students might face a huge workload as teachers often substitute the meetings with more assignments (Chong \& Reinders, 2020). It can lead to a problem for the students as the tasks from all classes might pile up, causing them to submit tasks after deadlines (Francisco \& Barcelona, 2020). The students might also encounter problems with their tools, as not all can have the same facility for their learning (Cojocariu \& Boghian, 2014).

\section{Method}

This research intended to study the Educational Psychology classroom activities using the CHAT framework. This study is qualitative research using an observational design. The researchers conducted observation and semi-structured interviews to gather the data.

The observation studied the existing data (Streefkerk, 2019). It was conducted on the LMS (www.belajar.usd.ac.id) and the WhatsApp group. The main focus of the observation on those two platforms was to gather information regarding the subject, object, outcomes, community, rules, tools, and divisions of labor. The semi-structured interviews collected information from individuals, particularly the class members. In this study, the interview participants were two students of the Educational Psychology class, selected using convenient sampling (Ary, Jacobs, Sorensen, \& Razavieh, 2010). 
The first interview participant (IP01) was a full-time teacher when he joined this class. Therefore, the participant had his preferences, contradictions, and contestations in several aspects of Educational Psychology's classroom management. He was an experienced teacher and aged around 40 years old. On the other hand, the second interview participant (IPO2) was also a master's student of English education, and he was just a regular student, though he used to teach at a private school. He was a younger student and around 25 years old. The participants had their preferences, and there are contradictions and contestations in some aspects of management and learning in educational psychology classes.

Both the observation and the semi-structured interviews were performed to gather information about the units of analysis (UoA) of CHAT. The semi-structured interviews were also especially used to discover the challenges in the activities. There were six items in the semistructured interview guideline to figure the students' challenges, based on the theories by Gedera (2015), Nussbaumer (2012), and Postholm (2015). In analyzing the observation data, the units of the analysis found in the LMS and group chat were noted down and coded. After being tabulated, they were grouped based on the UoA categories. The semi-structured interviews were conducted in 30 minutes to an hour. The interview results were then transcribed with nonverbatim transcription. Then, the challenges that the students faced from the interview were also tabulated and coded. The results were then coded and categorized into themes.

\section{Findings and Discussion}

\section{The Description of Units of Analysis (UoA)}

The UoA consists of the subject, object, outcome, tool, rule, community, and division of labor. From the observation on the LMS, WhatsApp Group (WAG), and sharing moments by considering CHAT, MA-TBLT, and self-regulation theories, the data to describe the UoA were gathered. Below are the descriptions of each unit:

Subject. The subjects of these activities are the Master of English Education students and lecturers. Subjects refer to students who used asynchronous discussion forums. As subjects, they understand that they are tied to this standard and work toward achieving the objectives (Engeström, Hakkarainen, \& Hedegaard, 1984). 
Object. The object is the use of asynchronous discussion forums for promoting critical thinking. The objects of these activities are the making of video presentations, scripts, and PPTs (Engeström, Hakkarainen, \& Hedegaard, 1984), revealing the basic inner relationship of the object system.

Outcome. Upon completing the activities throughout the semester, the students expected some outcomes. The activities done by the subjects alter the objects to the outcome (Issroff \& Scanlon, 2002; Roth \& Lee, 2007; Roth \& Tobin, 2002).

In this educational psychology class, the expected learning outcomes followed three areas of Ignatian pedagogy. Here are the outcomes taken from the course outline: (1) Competence: (a) Understand theories in educational psychology, (b) Understand various issues in self-regulation and metacognition in English language learning, (d) Produce publishable research papers on educational psychology in a reputable journal, and (d) Present research papers on educational psychology at a conference; (2) Conscience: (a) Gain more awareness of the important issues and debates in educational psychology, (b) Improve the responsibility and autonomy in writing educational psychology research papers; (3) Compassion: (a) Grow critical interests in the work of various scholars in educational psychology research, (b) Have a greater passion for educational psychology research, and (c) Work collaboratively to complete the assigned projects.

Tool. Tools refer to asynchronous discussion forums and language used to express student teachers' thoughts. In these activities, the tools are stuff the teachers and students use. Tools are divided into two parts, primary and secondary. LMS, laptop, cellphone, Zoom, YouTube, video, WAG come under the primary section, while critical thinking, ideas, and selfregulated learning belong to the secondary section. Tools can be physical (such as a computer, a pen), mental (a plan), psychological, symbolic or abstract (a language, an experience) or virtual (functions of a website). Tools have mediated the objective of activity and assisted in transforming an objective into an outcome. This element depicts the principle of mediation in an activity. However, there were still many obstacles in using tools discovered in this study, such as bad internet connection and lag or inaccessibility in using an LSM. Tools as the property of an individual or group of individuals did not emerge historically and collectively. According to Pohio (2016), an investigation of the communication tools facilitates the home-school community. 
Community. Being engaged in a collective activity, the subjects had a community around them. In this community, knowledge construction is promoted (Nussbaumer, 2012). The community in the Educational Psychology class consisted of 17 students and two lecturers. The students were from various backgrounds; a vocational high school teacher, English courses instructors, fresh graduate students, Passenger Survey Exit staff, university administration staff, and a KBI student (another study program). The lecturers taught in both undergraduate and master's programs.

Rule. In participating in this class, there were rules that the students should follow. In the activity theory, the rules regulate, mediate, and guide the interactions among the activity system components (Issroff \& Scanlon, 2002; Jonassen \& Rohrer-Murphy, 1999; Postholm, 2015). In this class, several rules were first made by the lecturers, as the examples shown, taken from the course outline: (1) For paper assignment: (a) The due date for the paper proposal/plan was the mid-term week, (b) The due date for the final paper draft was the final week, and (c) The composition of the final paper should follow the already given rubric. (2) For individual task assignments: (a) Read the journals and submit the worksheet on Sundays (first half) and Mondays (second half), (b) Make a self-reflection after the discussion on Tuesdays (first half), (c) Post the assigned worksheet answers and video links on Mondays (second half). (3) For the group presentation: (a) The assigned group posts a 10-minute video before the class, and each student submits the presentation and YouTube links individually (first half), (b) The presenting group may use video or present in Zoom meetings. If using YouTube, share the link on Monday; if directly presenting in Zoom, present for 30 minutes (second half). (4) For classroom discussion: (a) Raise questions or give comments to the presenting group in the YouTube comment section or LMS, and the presenters answer the questions (first half), (b) Raise questions or comments to the presenting group in the Zoom chat, and the presenters or other participants answer the questions (second half).

However, other rules, which directly concerned the students' tasks, were negotiable, and some were changed due to the discussion with the students: (1) Final task topic: either conducting a study or doing a library analysis; (2) Worksheet due date (first half): Sunday the latest; (3) Worksheet completion (second half): each student answers each worksheet number based on his/her presence number; (4) Zoom meetings: every other week (first half), every week 
(second half) for one to one and a half hours; and (5) Individual workload: reading only one journal is allowed (first half).

Division of Labor. The students were divided into groups with distinct duties in undertaking the activities. The MA-TBLT included the before, during, and after activities (Xue, 2020) and self-regulated students in those stages.

Horizontal and vertical divisions: (1) Horizontal: task division was in the group presentation assignment for five groups with 3-4 students in each group. Each group presented two topics. (2) Vertical division: lecturers as the highest position set the decisions and rules, the class captain delivered information from the lecturers to students and vice versa, and the rest of the students.

Self-regulation. (1) Pre-activity: started with choosing groups in the first week and students' metacognitive strategies before each activity to achieve the outcomes. (2) Mid-activity: monitoring emotion, time, effort management, and their control on their volition during worksheet completion, material discussion, and the final paper. (3) Post-activity: reflecting attitude and attribution in LMS, WAG, and sharing the moment.

The relationships among those units are presented in Figure 1. The subjects, objects, and outcomes were interrelated. Activity theory is goal-oriented, and it aims to have the expected outcomes as the actual results. The students aimed to achieve the expected outcomes and were affected by the objects as they should consider the effort, time, and other conditions needed. The objects, the media, topic, and activities bridged and were influenced by the students, who did the actions and outcomes. How the students utilized the objects influenced the actual outcomes. The relationship of those subjects, objects, and outcomes was mediated with other components: the tool, rule, community, and division of labor. The tools eased the activities performed by the subjects; the rules guided the subjects in doing the activities, using tools, and having relationships with the community; the community assisted the subjects in doing the tasks and helped knowledge construction; while the division of labor helped the individual subject in coping with the activities within himself/herself and also as a part of the community. 
Figure 1. The Units of Learning Activity System

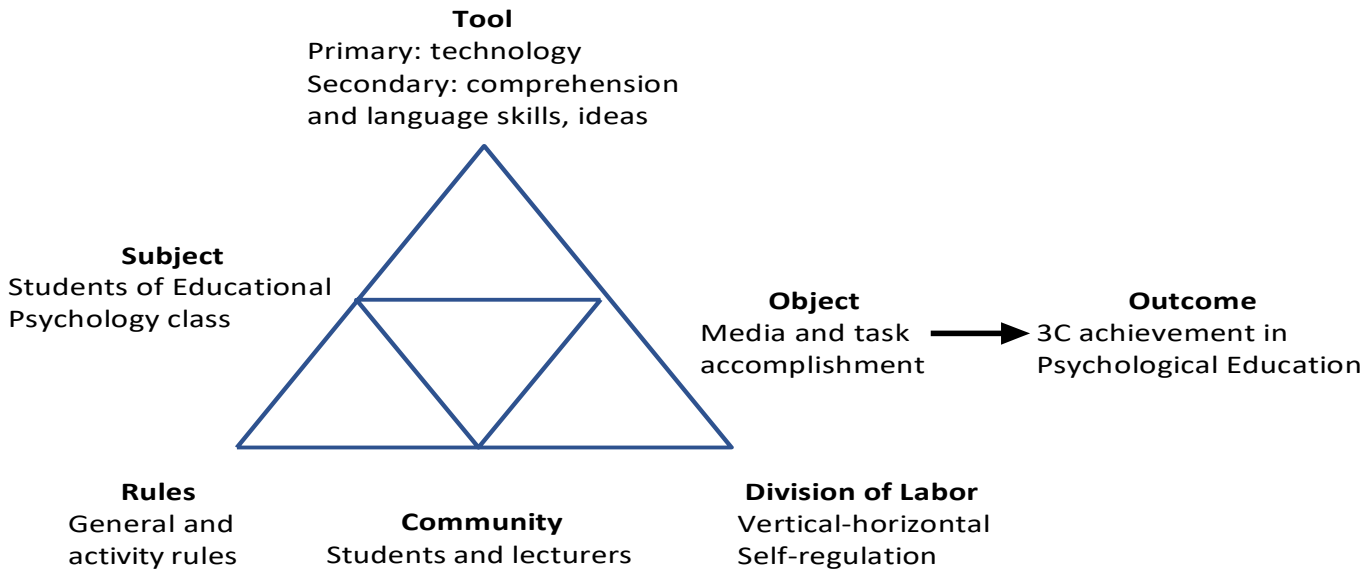

\section{The Challenges Faced by the Students}

In a transformation process, there will be challenges and obstacles. After gathering data by observing reflections and interviewing two students, the authors found several contradictions and tensions on preferences. The challenges faced by both students are:

Interview Participant 01 (IP01). The participant had his preferences and therefore had some contradictions and contestations in several aspects of Educational Psychology's classroom management.

Community. "I never contacted other students except if they were my group friends because I don't know them and I don't want to bother them. ... I actually like being among others when learning. Because of that, I also felt like I'm alone and I had to work by myself during online classes."

Relationship with others. The participant encountered problems in being close with others and knowing them. He did not know the interlocutors' personalities nor how to approach them, so he observed the students and only talked with the familiar ones. He preferred to be contacted first because he felt reluctant to contact others first or pekewuh in Javanese. He did not want to disturb lecturers' private time, though they allowed that for consultation. The online environment hinders students from forming a sense of community, so it is the teachers' role to initiate it (Stewart, 2008). 
Perceived loneliness. IP01 felt like he was the only person who had problems completing his tasks. He perceived that other students did well and were better than him. This perceived loneliness was caused by the lack of face-to-face meetings for him and other students to be close and share their problems. In an online community with the absence of other students and teachers, the students can feel alone with their learning, including their tasks (Stewart, 2008).

Rules. "We have a lot of readings, plus we had to read even more for our final paper. Sometimes, it's overwhelming."

Deadline. To IP01, the amount of the reading was too much for the given deadline. The reading workload was too heavy if combined with other tasks and the final project. The readings caused a heavy workload for the students and were also time-consuming (Chong \& Reinders, 2020), so teachers should consider the workload and flexibility (Chong \& Reinders, 2020; Francisco \& Barcelona, 2020). IP01 often did self-paced learning. He completed the tasks in his free time since he also had a job to work on. To assist students' special needs, the teachers can design the class to either be self-paced or time-driven (Francisco \& Barcelona, 2020).

Division of labor. "The group works were difficult as I often feel reluctant to speak up first, and I much prefer individual tasks because I don't want to hold the group down. ... all subjects had an essay in the end, and I prefer making videos more. I believe research paper is more time-consuming."

Work distribution. In work distribution, IP01 preferred to be directed. It would take a long time if the group members discussed only the work distribution, so he preferred that they just pick their own duty and left him some to work on.

Work form. He preferred to make presentation videos rather than paper, although it would be useful for his graduation since those would be beneficial in teaching, and he liked making videos.

Community and division of labor. "Because of that, I also felt like I'm alone and I had to work by myself during online classes. If we meet, we can discuss, know each other, and have better learning atmosphere overall that improve the mood. ... I also sometimes feel anxious in group works because and I don't know if they think I do good enough work."

Perceived loneliness with attribution. Offline classes hamper the sense of community. The feeling of being the only one who struggled a lot affected students' attribution (Turner \& 
Husman, 2008). OP01 disliked not having offline meetings; he believed he could manage his time, feeling, and work better if he had those.

Working community with preference. OP01 chose to work on his tasks by himself. In shared accountability, he often worried about making a satisfactory or enough contribution according to others' standards. He could show his level of ability and proficiency in this class if he worked by himself without the pressure to 'help' or 'satisfy' others to achieve a good enough score and submit on time.

Rules, tools, and division of labor. "Other students offered me to just copy the work, as it won't be graded, but I think it's better if I submit late rather than copying. Task grading policy is also a problem, because why bother giving such big workload if it is not graded. As for the final paper, it's honestly hard to work on it among my tasks as a teacher."

Individual reading with self-value. The participant chose to submit his work late rather than adapting his friend's work. Others offered him answers, and the rule allowed collaborative work. However, his integrity prohibited him from adapting others' work before reading the journals. By acting on his standards and values, he achieved self-satisfaction in learning (Bandura \& Locke, 2003).

Individual reading with an attitude. Worksheets were done every week, but the lecturers did not give any feedback on them. IP01 gave this task high regard, which was his attitude toward the task, while the lecturers just used that for pre-meeting activity. The deadline rule without a clear statement about the purpose of the task caused tension between the participant's attitude (and expectation) and the rule.

Classroom discussion with the primary tool. Discussion in the YouTube comment was viewed as less interactive and systematic than LMS. The discussion utilized YouTube comments because the LMS often lagged. He was fine with that, but it was not highly interactive because students only had to comment on anything and the presenting group responded. Unlike LMS, lecturers would not know who had not commented. He opted for LMS more, but he knew students often had problems accessing it.

Paper-project with secondary tool and volition. The paper project was the most challenging activity. He had not decided on the paper topic in tools as per this interview day. It was not because he lacked English proficiencies or knowledge in Educational Psychology, but 
because he could not regulate his knowledge. He also had trouble motivating his actual actions because he got distracted with his job. After work, he could not maintain his motivation to work on his paper. The teacher can help by giving instructions on behaviors in both study and volitional strategies (Turner \& Husman, 2008).

\section{Interview Participant 02 (IP02)}

Similar to the first interview participant, the second interview participant had his preferences and therefore had some contradictions and contestations in several aspects of Educational Psychology's classroom management.

Tools. "I stay in my hometown instead of living near campus, and I often have troubles with my tools, especially the internet. ... Because I often miss classes, and sometimes notices, I am worried if I miss any tasks or important announcements like administrations."

Inadequate facilities. The participant had problems with tools. The problem was about internet facilities, laptops and cell phones which were inadequate to support the learning process (Cojocariu \& Boghian, 2014). Sometimes, participants had difficulty getting an internet signal to participate in the learning process. To get an internet signal, they had to put their cell phone on a cupboard or window to learn comfortably, but sometimes the effort was not always successful. He preferred to watch videos or ask friends who were indeed able to follow the lesson quite fluently, to be able to explain to him about what material was being studied that day or about the assignments given by the lecturers to students.

Perceived worry. The lack of adequate facilities may cause worries for students, especially if they cannot follow the class properly. Tools such as the internet, laptops and cell phones are crucial to support online learning properly, but on the other hand, it is one of the most difficult things for students who may not have adequate facilities at home, so lecturers have to work harder to provide the best solution in this problem. Baralt, Gurzynski-Weiss, \& Kim (2017) suggested that online learning may be less effective than classroom learning as students are less engaged. Tang (2019) argued that face-to-face learning is more effective than online learning. While most had used some online tools as supplements to their classroom teaching, very few had taught whole courses online. 
Community. "I rarely talk with the lecturer or students outside the class because I don't want to disturb them."

Relationship between lecturers and students. Participants also had problems with the community on how the relationship between lecturers and students was not close enough because they could not meet face-to-face in class learning. Participants had difficulty getting closer to classmates because they could not meet face to face directly. Participants felt that online meetings had many restrictions that could not be carried out when meeting in person. He also felt that he could not get to know friends or lecturers closely because he did not know the personality of the other person or how to approach them. During this online learning, he observed other students more often and talked to those he already knew. He was also not used to contacting or asking unimportant questions to lecturers or friends he may not know closely because he was uncomfortable. Online learning has made students have a distance from friends and lecturers to build or form a harmonious community with class members so that the role of lecturers is crucial to build a sense of togetherness and community in online learning currently being undertaken (Stewart, 2008). This situation may make him feel that his abilities are not that good from his other friends.

Rules. "I can handle the assignment but I need longer deadline, it's too much if we only have a week."

Collection of assignments. IP02 had problems regarding the distribution of time in the work of assignments and deadlines for assigning assignments made by the lecturer. In one week, the lecturer gave three readings and still had to do the assignments that had to be collected at the LMS with a fairly close deadline. He felt that the number of readings given by the lecturer was too much within a fairly small period. Excessive tasks could provide time and mental pressure for students (Rees \& Redfern, 2000) to read three readings given by the lecturer. He had to manage his time between one subject's assignments and another and adjust to his busy life. Dayto-day, even though he no longer worked formally, he was quite overwhelmed in dividing his time to do all his lecture responsibilities within one week. The university needs to maintain a well-balanced academic environment conducive to better learning, focusing on the students' personal needs (Elfering et al., 2005). In this case, the lecturer must pay attention to the workload and the time each student has. 


\section{Conclusion and Implication}

This research explored the activities in Educational Psychology and the challenges faced by the students using the activity theory. There were seven activity components in Educational Psychology class, including the subject (students), object (media and task achievement), outcomes (according to 3C Ignatian pedagogy), tools (technology and students' knowledge), rules (general and activity rules), and division of labor (horizontal-vertical division and self-regulation). In addition, the students also faced challenges in the form of tensions and preferences when undergoing the Educational Psychology class. Those challenges were related to the technology, community, deadline instructions, workload, and students' self-regulation. This research was still limited because of the small number of samples so that future researchers could use another sampling in different classes. The implications of this study are for the teachers to utilize the CHAT framework to identify the tensions, conflicts, contradictions, and issues within the class and for the teachers and students to evaluate the learning process together.

\section{References}

Allen, D., Karanasios, S., \& Slavova, M. (2011). Working with activity theory: Context, technology, and information behavior. Journal of the American Society for Information Science and Technology. 62(4), 776-788. https://doi.org/10.1002/asi.21441

Arvanitis, P., Krystalli, P., \& Panagiotidis, P. (2016). Applications for mobile assisted language learning: A current field research. INTED2016, 7645-7651. https://doi.org/10.21125/inted.2016.0803.

Ary, D., Jacobs, L. C., Sorensen, C., \& Razavieh, A. (2010). Introduction to research in education (8th ed.). Wadsworth.

Bandura, A., \& Locke, E. A. (2003). Negative self-efficacy and goal effects revisited. Journalof Applied Psychology, 88, 87-99. https://psycnet.apa.org/doi/10.1037/0021-9010.88.1.87

Baralt, M., Gurzynski-Weiss, L. \& Kim, Y. (2016). Engagement with the language: How examining learners' affective and social engagement explains successful learner- 
generated attention to form. In M. Sato \& S. Ballinger (Eds.), Peer interaction and second language learning. Pedagogical potential and research agenda (pp. 209-240). John Benjamins.

Chong S.W., \& Reinders H. (2020). Technology-mediated task-based language teaching: A qualitative research synthesis. Language Learning $\mathcal{E}$ Technology, 24(3), 70-86. Retrieved from http://hdl.handle.net/10125/44739

Cojocariu, V. M., \& Boghian, I. (2014). Teaching the relevance of game-based learning to preschool and primary teachers. Procedia-Social and Behavioral Sciences, 142, 640-646. https://doi.org/10.1016/j.sbspro.2014.07.679

Davydov, V. V. (2008). Problems of developmental instruction: A theoretical and experimental psychological study. Nova Science Publishers.

Elfering, A., Grebner, S., K Semmer, N., Kaiser-Freiburghaus, D., Lauper-Del Ponte, S., \& Witschi, I. (2005). Chronic job stressors and job control: Effects on event-related coping success and well-being. Journal of Occupational and Organizational Psychology, 78(2),237252. https://doi.org/10.1348/096317905X40088

Engeström, Y., Hakkarainen, P., \& Hedegaard, M. (1984). On the methodological basis of research in teaching and learning. In M. Hedegaard, P. Hakkarainen \& Y. Engeström (Eds), Learning and teaching on a scientific basis: Methodological and epistemologicalaspect of the Activity theory of learning and teaching (pp.119-189). Psykologisk Institut, Aarhus Universitet.

Engestrom, Y. (2000). Activity theory as a framework for analyzing and redesigning work. Ergonomics 43(7), 960-974. https://doi.org/10.1080/001401300409143.

Engeström, Y. (2015). Learning by expanding (2 ${ }^{\text {nd }}$ ed.). Cambridge University Press.

Engeström, Y., \& Pyörälä, E. (2020). Using activity theory to transform medical work and learning. Medical Teacher. https://doi.org/10.1080/0142159X.2020.1795105. 
Estarki, N. K., \& Bazyar, M. (2016). The effect of MALL on pre-intermediate EFL learners' writing performance. European Online Journal of Natural and Social Sciences, 5(2), 406-420. Retrieved from https://www.european-science.com.

Francisco, C. D. C. \& M. C. Barcelona. (2020). Effectiveness of an Online Classroom for Flexible Learning. International Journal of Academic Multidisciplinary Research 4(8), 100 107. Retrieved from https:// www.ijeais.org/ijamr.

Gacs, A., Goertler, R., \& Spasova, S. (2020). Planned online language education versus crisisprompted online language teaching: Lessons for the future. Foreign Language Annals, 53(2), 380-392. https://doi.org/10.1111/flan.12460

Gedera, D. S. P. (2015). The application of activity theory in identifying contradictions in a university blended learning course. In D. S. P. Gedera \& P. J. Williams (Eds.), Activity theory in education: Research and practice (pp. 53-70). Rotterdam: Sense Publishers. https://doi.org/10.1007/978-94-6300-387-2 4.

Issroff, K., \& Scanlon, E. (2002). Using technology in higher education: An activity theory perspective. Journal of Computer Assisted Learning 18, 77-83. https://doi.org/10.1046/j.0266-4909.2001.00213.x.

Jonassen, D. H., \& Rohrer-Murphy, L. (1999). Activity theory as a framework for designing constructivist learning environments. Educational Technology Research andDevelopment, 47(1), 61-79. https://doi.org/10.1007/BF02299477.

Leontiev, A. N. (1978). Activity, consciousness, and personality. Pergamon Press.

Leontiev, A. N. (1981). Problems of the development of the mind. Progress Publishers.

Namaziandost, I., Bohloulzadeh, G., \& Pazhakh, A. (2017). The effect of task-based language teaching on motivation and grammatical achievement of EFL junior high school students. Advances in Language and Literary Studies, 8(2). https://doi.org/10.7575/aiac.alls.v.8n.2p.243.

Nussbaumer, D. (2012). An overview of cultural historical activity theory (CHAT) use in 
classroom research 2000 to 2009. In Educational Review 64(1), 27-55. https://doi.org/10.1080/00131911.2011.553947.

Pintrich, P. R. (2000). The Role of Goal Orientation in Self-Regulated Learning. In M. Boekaerts, P. R. Pintrich, \& M. Zeidner (Eds.), Handbook of Self-Regulation. Cambridge: Academic Press. https://doi.org/10.1016/b978-012109890-2/50043-3.

Postholm, M. B. (2015). Methodologies in cultural-historical activity theory: The example of school-based development. Educational Research, 57(1), 43 58. https://doi.org/10.1080/00131881.2014.983723.

Quinton, S. \& Allen, M. (2014 ). Collaboration: Towards a new model for virtual learning in Gosper, M. and Ifenthaler, D. (eds.). Curriculum Models for the 21st Century: Using Learning Technologies in Higher Education. Springer

Rees, C. J., \& Redfern, D. (2000). Recognising the perceived causes of stress-a training and development perspective. Industrial and Commercial Training.

Roth, W. M., \& Lee, Y. J. (2007). “Vygotsky's neglected legacy”: Cultural-historical activity theory. Review of Educational Research 77(2), 186232. https://doi.org/10.3102/0034654306298273.

Roth, W. M., \& Tobin, K. (2002). Redesigning an "urban” teacher education program: Anactivity theory perspective. Mind, Culture, and Activity 9(2) 108131. https://doi.org/10.1207/S15327884MCA0902 03.

Saka, Y., Southerland, S. A., \& Brooks, J. S. (2009). Becoming a member of a school community while working toward science education reform: Teacher induction from a cultural historical activity theory (CHAT) perspective. Science Education, 93(6), 9961025 .

Streefkerk, R. (2019). Qualitative vs. Quantitative Research: Differences $\mathcal{E}$ methods. Retrieved from https://www.scribbr.com/methodology/qualitative-quantitative-research (accessed on July 2, 2020). 
Stewart, D. P. (2008). Classroom management in the online environment. MERLOT Journal of Online Learning and Teaching, 4(3), 371-374. Retrieved from http://jolt.merlot.org/vol4no3/ stewart_0908.pdf.

Tang, X. (2019). The effects of task modality on L2 Chinese learners' pragmatic development: Computer-mediated written chat vs. face-to-face oral chat. System 80, 48-59. https://doi.org/10.1016/j.system.2018.10.011

Thomas, M., \& Reinders, H. (2010). Task based language learning and teaching with technology. Continuum.

Turner, J. E., \& Husman, J. (2008). Emotional and Cognitive Self-Regulation Following Academic Shame. Journal of Advanced Academics 20(1), 138-173. https://doi.org/10.4219/jaa-2008-864

Vlachopoulos, P., \& Cowan, J. (2010). Reconceptualising moderation in asynchronous online discussion using grounded theory. Distance Education, 31(1), 23-26. https://doi.org/10.1080/01587911003724611

Vygotsky, L.S. (1978). Socio-cultural theory. Mind in society, 52-58.

Yamagata-Lynch, L.C. (2010). Activity systems analysis methods: Understanding complex learning environments. Springer Science \& Business Media.

Xue, S. (2020). A conceptual model for integrating affordances of mobile technologies into task-based language teaching. Interactive Learning Environments. https://doi.org/10.1080/10494820.2019.1711132

Ziegler, N. (2016). Taking technology to task: Technology-mediated TBLT, performance, and production. Annual Review of Applied Linguistics, 36, 136-163. https://doi.org/10.1017/S0267190516000039. 